University of Nebraska - Lincoln

DigitalCommons@University of Nebraska - Lincoln

Agronomy \& Horticulture -- Faculty Publications

Agronomy and Horticulture Department

$5-1990$

\title{
Registration of NP30, A Low-Dhurrin Sudangrass Population Selected for Regrowth Potential
}

Herman J. Gorz

United States Department of Agriculture

Francis A. Haskins

University of Nebraska-Lincoln, fhaskins@neb.rr.com

K. P. Vogel

United States Department of Agriculture, kvogel1@unl.edu

Follow this and additional works at: https://digitalcommons.unl.edu/agronomyfacpub

Part of the Plant Sciences Commons

Gorz, Herman J.; Haskins, Francis A.; and Vogel, K. P., "Registration of NP30, A Low-Dhurrin Sudangrass Population Selected for Regrowth Potential" (1990). Agronomy \& Horticulture -- Faculty Publications. 235. https://digitalcommons.unl.edu/agronomyfacpub/235

This Article is brought to you for free and open access by the Agronomy and Horticulture Department at DigitalCommons@University of Nebraska - Lincoln. It has been accepted for inclusion in Agronomy \& Horticulture -Faculty Publications by an authorized administrator of DigitalCommons@University of Nebraska - Lincoln. 
ratings were then used to differentiate the $S_{1} s$ with superior regrowth potential.

During the winter of 1986 to 1987 , remnant seed of the selected $S_{1} s$ was used to establish three plants of each of the 85 families in a greenhouse isolation in order to allow random mating among the families. Cross-pollinated seed, harvested from 35 male-sterile plants, was seeded in a field isolation in 1987 for a second random mating and seed increase. Seed for distribution was harvested separately from male-sterile (GP-238) and fertile plants. The yield of regrowth from the released population has not been determined nor compared with other sudangrass cultivars or populations.

NP30 should have value primarily as a potential source of low-dhurrin sudangrass germplasm with improved regrowth after repeated harvesting. The population segregates for plant color as well as for white or green midrib color, contains the $\mathrm{ms}_{3}$ gene for genetic male sterility, and averages $240 \mathrm{~cm}$ in height at maturity. Glume color is mostly black, mahogany, and sienna; and caryopsis color is brown.

The spectrophotometric assay for dhurrin (1) as measured by hydrocyanic acid potential of first leaves from 1-wk-old seedlings grown in the same test resulted in the following values for means and standard errors ( $\mathrm{mg} \mathrm{kg}^{-1}$ fresh weight, bulk of 10 seedlings per replication, three replications): NP30 fertile bulk $-252 \pm 22$; NP30 male-sterile bulk $-248 \pm 12$ NP25 fertile bulk-181 \pm 11 ; NP25 male-sterile bulk-228 \pm 26 ; 'Piper'-325 \pm 12 ; and 'Greenleaf' $-567 \pm 32$.

Seed will be maintained and distributed by the Department of Agronomy, University of Nebraska, Lincoln, NE 68583. Germplasm amounts will be provided without cost to each applicant upon written request while supplies last. Two different types of NP30 are available for distribution: (i) bulked seed harvested from genetic male-sterile plants (GP-238), and (ii) bulked seed harvested from fertile plants. Recipients of the seed are asked to make appropriate recognition of the source of the germplasm if it is used in the development of a new germplasm, parental line, cultivar, or hybrid.

H. J. GoRz*, F. A. HASKINS, AND K. P. VOGEL (6)

\section{REGISTRATION OF NP30, A LOW-DHURRIN SUDANGRASS POPULATION SELECTED FOR REGROWTH POTENTIAL}

NP30 SUDANGRASS [Sorghum bicolor (L.) Moench] [formerly S. sudanense (Piper) Staph] (Reg. no. GP-238, PI 535774) is a low-dhurrin, random-mating population developed cooperatively by the USDA-ARS and the Nebraska Agricultural Research Division. The population was released in April 1989. NP30 was synthesized from $85 S_{1}$ families selected from a total of 757 families that were evaluated for regrowth potential. The germplasm sources evaluated included $50 \mathrm{~S}_{1}$ families from the NP25(3) sudangrass population, 90 from NP28(2), 284 from NP29(4), 200 from NP31(5), 50 from NP32(5), and $83 S_{1}$ families from miscellaneous breeding lines low in dhurrin. The $85 \mathrm{~S}_{1}$ families selected for superior regrowth were derived from only two of the above sources with $42 \mathrm{~S}_{1} \mathrm{~s}$ being selected from NP29 and $43 S_{1}$ s from NP31. Both NP29 and NP31 carried the $m s_{3}$ gene for genetic male-sterility.

The development of NP30 involved only one cycle of selection for regrowth potential. Single $6.7-\mathrm{m}$ rows of each $S_{1}$, spaced $0.76 \mathrm{~m}$ apart, were planted on 12 May 1986 . The top growth in each row was mowed six times during the growing season with a rotary mower set at a height of $10 \mathrm{~cm}$. Rows were mowed $45,56,67,80,94$, and $105 \mathrm{~d}$ after planting, and average plant heights at the time of mowing were 75 , $45,50,56,40$, and $35 \mathrm{~cm}$, respectively. The regrowth in each row was given a visual rating prior to the last two mowings and again one month after the final mowing. These three

\section{References and Notes}

1. Gorz, H.J., W.L. Haag, J.E. Specht, and F.A. Haskins. 1977. Assay of phydroxybenzaldehyde as a measure of hydrocyanic acid potential in sorghums. Crop Sci. 17:578-582.

2. Gorz, H.J., F.A. Haskins, and K.P. Vogel. 1990. Registration of NP28 sudangrass germplasm, a composite of 90 low-dhurrin self-pollinated lines. Crop Sci. 30:000 $\rightarrow 000$.

3. Haskins, F.A., H.J. Gorz, S.D. Kindler, S.G. Jensen, and A. SotomayorRios. 1986. Registration of NP25 low-dhurrin sudangrass germplasm. Crop Sci. 26:213

4. Haskins, F.A., H.J. Gorz, and K.P. Vogel. 1990. Registration of NP29, a low-dhurrin sudangrass population selected for tolerance to early spring seeding. Crop Sci. 30:758-759.

5. Haskins, F.A., H.J. Gorz, and K.P. Vogel. 1990. Registration of NP31 and NP32, two populations of sudangrass selected for low-dhurrin content. Crop Sci. 30:759-760.

6. H.J. Gorz (retired) and K.P. Vogel, USDA-ARS; and F.A. Haskins (retired), Dep. of Agronomy, University of Nebraska, Lincoln, NE 68583. Cooperative investigations of USDA-ARS and the Nebraska Agric. Res. Division. Published as Journal Series Paper no. 8933., Nebraska Agric Res. Division. Registration by CSSA. Accepted 31 Aug. 1989. *Corresponding author.

Published in Crop Sci. 30:759 (1990). 